\title{
Aktifasi Tempurung Kelapa Untuk Mereduksi Emisi Gas Buang Motor Bakar
}

\author{
Yuniarto Agus Winoko $^{1}$, Ageng Gumelar Wicaksono ${ }^{2}$ \\ Program Studi DIV Teknik Otomotif Elektronik Jurusan Teknik Mesin, Politeknik Negeri Malang, Indonesia ${ }^{1,2}$ \\ Email: dhimazyuni@gmail.com ${ }^{1}$, agenggumelarwicaksono@gmail.com ${ }^{2}$ \\ DOI: http://dx.doi.org/10.31869/rtj.v4i1.2211
}

\begin{abstract}
Abstrak: Penggunaan karbon aktif sebagai katalis mempunyai keuntungan diantaranya dapat menghilangkan bau, penyerapan warna, zat purifikasi, sebagai adsorben, berpori, dan daya ikatnya kuat terhadap zat yang hendak dipisahkan secara fisik atau kimiawi.

Tujuan penelitian mengomparasikan emisi gas buang sepeda motor setelah dan sebelum terpasang adsorben pada knalpot dan menganalisis pengaruhnya terhadap putaran mesin $\mathrm{CO}, \mathrm{HC}$, dan $\mathrm{CO}_{2}$. Metode menggunakan eksperimen laboratorium dengan massa karbon aktif untuk mendapatkan data. Variabel bebas penelitian ini massa karbon aktif dan putaran mesin dan variabel terikatnya emisi $\mathrm{CO}, \mathrm{HC}$, dan $\mathrm{CO}_{2}$. Selanjutnya data hasil penelitian tersaji dalam dalam bentuk grafik dan menganalisisnya dengan menggunakan two way anova.

Hasil menunjukkan penurunan $\mathrm{CO}$ sebesar $12,06 \%$, $\mathrm{HC} 17,58 \%$, dan $\mathrm{CO}_{2} 8,14 \%$ pada penggunaan adsorben karbon aktif 200 gram.
\end{abstract}

Kata kunci: adsorben, karbon aktif, emisi gas buang

\section{PENDAHULUAN}

Tempurung kelapa selain dapat digunakan sebagai bahan bakar langsung maupun dalam bentuk arang, dapat juga digunakan sebagai bahan adsorpsi setelah diubah menjadi arang aktif atau karbon aktif. Arang aktif adalah arang yang mempunyai kemampuan daya absorpsi lebih tinggi dari arang pada umumnya. Karbon aktif tempurung kelapa dapat digunakan sebagai adsorben disebabkan memiliki banyak keuntungan seperti mempunyai daya adsorpsi yang selektif, berpori, dan mempunyai daya ikat yang kuat terhadap zat yang hendak dipisahkan secara fisik atau kimiawi.

Sudah banyak upaya yang dilakukan untuk mengurangi masalah polusi udara diantaranya penelitian yang menggunakan bahan limbah kulit buah durian sebagai karbon aktif yang digunakan pada kendaraan bermotor roda dua untuk menyerap emisi gas CO. Dari hasil penelitian menunjukkan karbon aktif tanpa penambahan $\mathrm{TiO}_{2}$ dapat menurunkan konsentrasi gas $\mathrm{CO}$ dari $0,604 \%$ menjadi $0,192 \%$, sehingga daya adsorpsi karbon aktif $68,2 \%$. Karbon aktif dengan penambahan $\mathrm{TiO}_{2}$ memiliki daya adsorbsi $97,8 \%$, menurunkan konsentrasi gas CO dari $0,604 \%$ menjadi $0,0135 \%$. Karbon aktif dengan penambahan $\mathrm{TiO}_{2}$ lebih optimal dalam menurunkan konsentrasi gas $\mathrm{CO}$, dibandingkan karbon aktif tanpa penambahan $\mathrm{TiO}_{2}$. Berdasarkan penelitian yang telah dilakukan sebelumnya, menunjukkan bahwa emisi gas buang dapat dikurangi dengan penambahan karbon aktif.

Karbon aktif dapat dibuat dari material yang mengandung karbon. Salah satu material yang mengandung karbon adalah tempurung kelapa.
Arang aktif tempurung kelapa mampu menurunkan konsentrasi berbagai polutan di udara termasuk $\mathrm{CO}$, NO, dan NOx karena memiliki daya adsorpsi dan luas permukaan yang baik. Indonesia sebagai negara tropis memiliki sumber daya alam yang sangat berlimpah seperti buah kelapa (Cocos nucifera) yang pemanfaatannya masih sangat terbuka guna dikaji dan dikembangkan lebih lanjut untuk dapat dimanfaatkan secara optimal. Hal ini juga mengingat bahwa meskipun hampir semua bagian dari buah kelapa telah diambil manfaatnya namun banyak pula yang terbuang menjadi sampah seperti pada bagian tempurungnya. Maka dari itu peneliti menggunakan limbah tempurung kelapa sebagai karbon aktif yang akan digunakan sebagai adsorben dengan tujuan mengomparasikan emisi gas buang sepeda motor setelah dan sebelum terpasang adsorben pada knalpot serta menganalisis pengaruh penggunaan adsorben karbon aktif berbahan dasar tempurung kelapa dan putaran mesin terhadap emisi gas buang sepeda motor $\left(\mathrm{CO}, \mathrm{HC}\right.$, dan $\left.\mathrm{CO}_{2}\right)$. 


\section{METODOLOGI PENELITIAN Diagram Alir Penelitian}

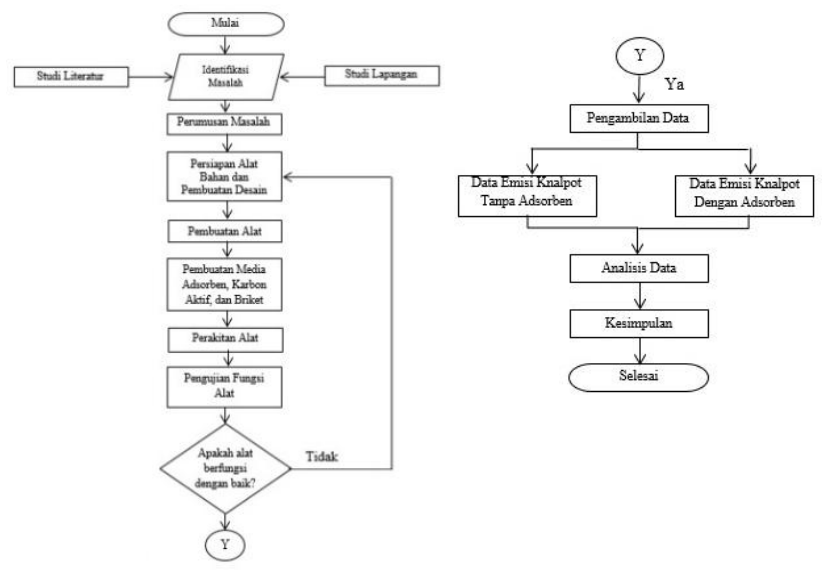

Gambar 1 Diagram Alir Penelitian

\section{Variabel Penelitian}

Variabel bebas pada penelitian ini adalah penambahan karbon aktif sebagai adsorben pada knalpot dengan massa 100 dan 200 gram dan variasi putaran engine pada sepeda motor $(2500,3000$, 3500, 4000, 4500, 5000, 5500, 6000, dan $6500 \mathrm{rpm}$ ). Variabel terikat pada penelitian ini adalah emisi gas buang $\mathrm{CO}, \mathrm{HC}$, dan $\mathrm{CO}_{2}$.

\section{Prosedur Penelitian}

a. Pembuatan karbon aktif (dehidrasi dan karbonisasi)

Proses pertama dalam pembuatan karbon aktif yaitu pencarian bahan baku yaitu limbah tempurung kelapa yang terdapat pada pedagang-pedagang kelapa yang berada di pasar Merjosari, Kota Malang. Proses dehidrasi tempurung kelapa dilakukan dengan cara memecah tempurung kelapa hingga kecil-kecil bentuknya lalu tempurung kelapa dijemur dibawah sinar matahari selama 8 jam. Proses kedua yaitu proses karbonisasi, proses karbonisasi pada penelitian ini dilakukan dengan cara memasukkan tempurung kelapa yang sudah ditaruh di dalam crucible porcelain $50 \mathrm{ml}$ kemudian dipanaskan di dalam furnace dengan temperatur $500^{\circ} \mathrm{C}$ selama 90 menit.

b. Pembuatan karbon aktif (aktivasi)

Proses ketiga yaitu aktivasi, pada penilitian ini larutan pengaktif yang digunakan adalah Natrium Klorida $(\mathrm{NaCl})$ 20\%. Sebelum direndam dengan larutan $\mathrm{NaCl}$ serbuk karbon yang dihasilkan dari proses karbonisasi diblender kemudian disaring menggunakan ayakan 60 mesh agar didapat ukuran serbuk karbon yang sama besarnya. Perbandingan serbuk karbon dengan larutan $\mathrm{NaCl}$ yaitu 1:3 (1 gram serbuk karbon : $3 \mathrm{ml}$ larutan $\mathrm{NaCl}$ ). Serbuk karbon yang telah lolos saringan kemudian direndam dengan larutan Natrium Klorida $(\mathrm{NaCl})$ selama 24 jam. Setelah dilakukan perendaman tahap selanjutnya serbuk karbon disaring menggunakan kertas saring dan dicuci menggunakan aquades sampai air cucian bersih dan $\mathrm{pH}$ mendekati netral. Kemudian serbuk karbon yang masih basah dijemur dibawah sinar matahari selama 1 hari. Setelah itu serbuk karbon di masukkan kedalam crucible porcelain $50 \mathrm{ml}$ dan di oven pada suhu $105^{\circ} \mathrm{C}$ selama 3 jam.

c. Pembuatan media adsorpsi

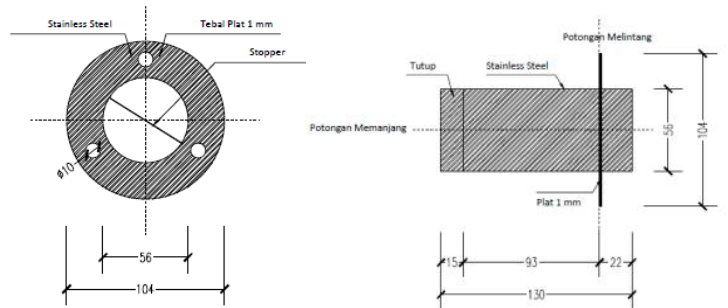

Gambar 2 Rancangan Media Adsorpsi

Media adsorpsi terdiri dari dua bagian yaitu media adsorben pipa stainless steel dengan ketebalan $1 \mathrm{~mm}$ dan rumah adsorben dibuat dari kawat kasa stainless steel 120 mesh. Adsorben dibuat dengan dua variasi massa yaitu 100 dan 200 gram.

d. Pengambilan data emisi gas buang

Pengambilan data emisi gas buang dilakukan dengan menggunakan alat Tecnotest MOD 488. Media adsorpsi yang telah dibuat dipasang pada knalpot. Untuk pengukuran dengan gas analyzer Tecnotest MOD 488 pertama alat harus dikalibrasi terlebih dahulu. Probe pada gas analyzer dimasukkan kedalam knalpot dengan panjang probe yang masuk $\pm 20-25 \mathrm{~cm}$. Data hasil pengujian emisi gas buang dapat dilihat pada LCD alat ukur Tecnotest MOD 488. Untuk Tecnotest MOD 488 jika data yang diambil dirasa cukup tekan hold pada alat ukur dan print untuk mencetak hasil pengukuran. Pengambilan data emisi gas buang tanpa penambahan adsorben langkah pengujiannya sama dengan penambahan adsorben. 


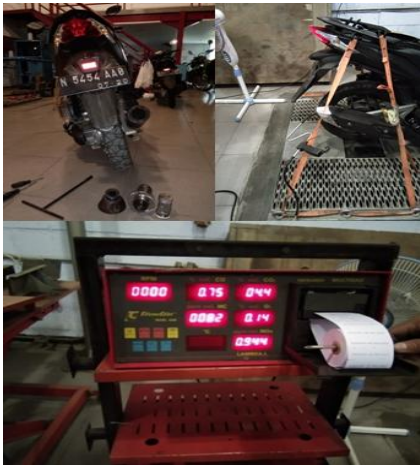

Gambar 3 Pengambilan Data Emisi Gas Buang

\section{HASIL DAN PEMBAHASAN}

Dalam penelitian yang dilakukan, penulis mendapatkan beberapa data berupa pengujian SEM $E D X$ karbon aktif sebelum aktivasi dan sesudah aktivasi, grafik pengaruh temperatur pemijaran karbon aktif dan grafik pengaruh luas permukaan karbon aktif terhadap emisi gas buang sepeda motor. Berikut adalah data hasil penelitian yang telah dilakukan :

\section{Pengujian SEM-EDX}

Dilakukan uji SEM EDX (Scanning Electronic Microscopy Energy Dispersive $X$-ray) yang bertujuan untuk mengetahui kandungan dan permukaan pada karbon aktif sebelum dan sesudah diaktivasi. Hasil dari uji SEM untuk karbon aktif tempurung kelapa dapat dilihat pada gambar 4 a dan b di bawah ini.

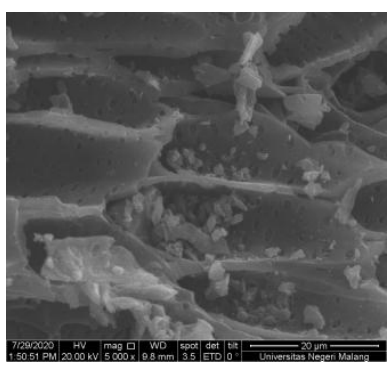

(a)

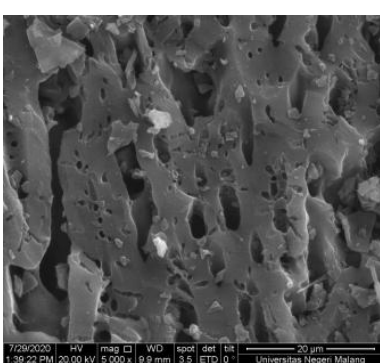

(b)
Gambar 4 (a) Permukaan Karbon Sebelum dan (b) Sesudah dilakukan Aktivasi (Sumber : Dokumentasi Pribadi)

Pada Gambar diatas menunjukkan permukaan dari karbon, dari gambar diatas terlihat perbedaan permukaan karbon sebelum diaktivasi dan sesudah diaktivasi. Hasil analisis morfologi permukaan karbon sebelum diaktivasi terlihat tidak beraturan sedangkan permukaan karbon aktif setelah diaktivasi terlihat lebih beraturan. Permukaan karbon aktif setelah diaktivasi menggunakan $\mathrm{NaCl}$ mengalami pembentukan permukaan baru yang lebih beraturan, pori pada karbon terbuka, dan permukaan adsorben terlihat lebih bersih.

\begin{tabular}{|c|l|l|}
\hline Element & $\boldsymbol{W t} \%$ & $\boldsymbol{A t} \%$ \\
\hline CK & 81.76 & 86.94 \\
OK & 15.06 & 12.02 \\
KK & 03.18 & 01.04 \\
Matrix & Correction & ZAF \\
\hline \hline
\end{tabular}

\begin{tabular}{|l|l|l|}
\hline Element & Wt $\%$ & At $\%$ \\
\hline CK & 84.91 & 88.68 \\
OK & 12.93 & 10.14 \\
NaK & 02.16 & 01.18 \\
\hline Matrix & Correction & ZAF \\
\hline
\end{tabular}

(a)

(b)

Gambar 5 (a) Kandungan Karbon Sebelum dan (b) Sesudah dilakukan Aktivasi

Pada gambar diatas menunjukkan kandungan karbon sebelum diaktivasi dan kandungan karbon setelah diaktivasi menggunakan $\mathrm{NaCl}$. Pada gambar diatas menunjukkan peningkatan kadar karbon aktif setelah dilakukan aktivasi dari $81,76 \%$ menjadi $84,91 \%$. Namun terjadi penurunan kadar oksigen setelah dilakukan aktivasi dari $15,06 \%$ menjadi $12,93 \%$, dan terdapat unsur kalium dengan kadar $03,18 \%$ pada karbon yang belum diaktivasi. Pada karbon yang sudah diaktivasi terdapat kandungan natrium sebesar 02,16 \%. Pada tabel tersebut Matrix adalah metode statistik yang digunakan untuk menganalisis kandungan yang terdapat pada karbon, sedangkan pengoreksinya menggunakan ZAF. Element pada tabel diatas merupakan unsur kandungan yang terdapat pada karbon, sedangkan $W t \%$ adalah persentase berat dari masing-masing unsur yang terdapat pada karbon dan $A t \%$ adalah persentase atom dari masing-masing unsur yang terdapat pada karbon.

\section{Pengaruh Variasi Massa Karbon Aktif terhadap Emisi Gas Buang Sepeda Motor}

CO

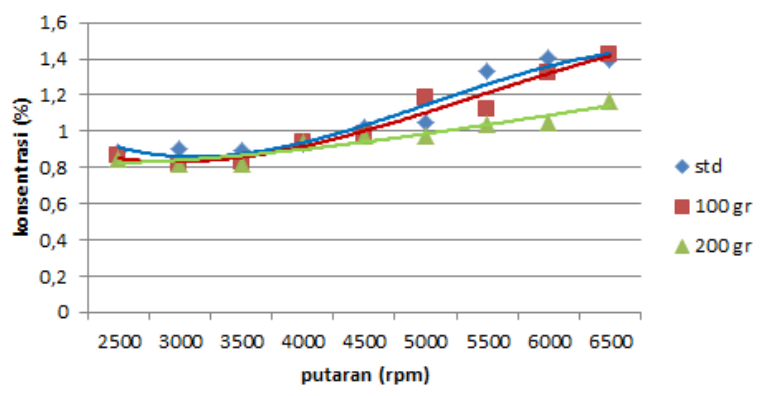

Gambar 6 Grafik Variasi Massa Karbon Aktif Terhadap Gas CO

Hasil yang ditunjukkan pada Gambar 6 di atas dapat diketahui bahwa penambahan adsorben berpengaruh terhadap emisi gas buang yang dihasilkan, dengan penambahan adsorben emisi gas buang yang dihasilkan lebih rendah daripada tanpa penambahan adsorben. Berdasarkan grafik diatas dapat diketahui bahwa penurunan emisi gas buang yang paling baik adalah pada variasi massa karbon 
aktif 200 gram dengan persentase penurunan kadar emisi sebesar $12,06 \%$.

\section{HC}

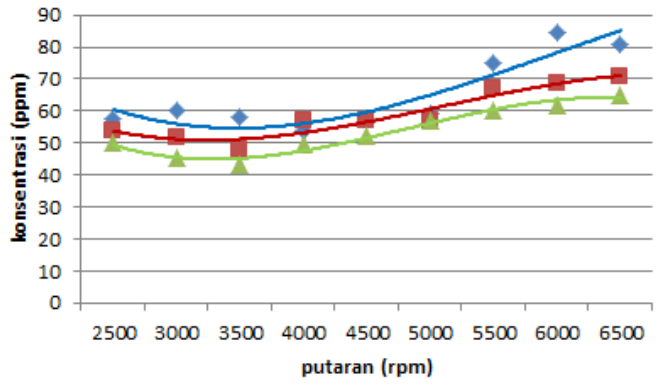

Gambar 7 Grafik Variasi Massa

Karbon Aktif Terhadap Gas HC

Berdasarkan Gambar 7 di atas dapat diketahui bahwa penambahan adsorben berpengaruh terhadap emisi gas buang yang dihasilkan, dengan penambahan adsorben emisi gas buang yang dihasilkan lebih rendah daripada tanpa penambahan adsorben. Berdasarkan grafik diatas dapat diketahui bahwa penurunan emisi gas buang yang paling baik adalah pada variasi massa karbon aktif 200 gram dengan persentase penurunan kadar emisi sebesar $17,58 \%$.

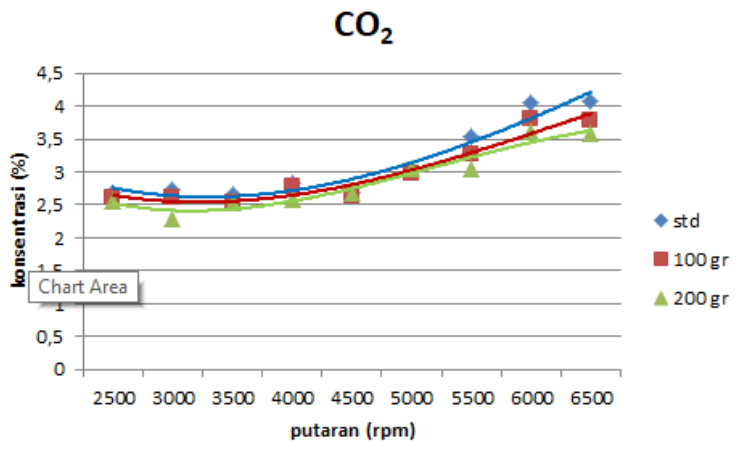

Gambar 8 Grafik Variasi Massa

Karbon Aktif Terhadap Gas $\mathrm{CO}_{2}$

Dari Gambar 8 di atas dapat diketahui bahwa penambahan adsorben berpengaruh terhadap emisi gas buang yang dihasilkan, dengan penambahan adsorben emisi gas buang yang dihasilkan lebih rendah daripada tanpa penambahan adsorben. Berdasarkan grafik diatas dapat diketahui bahwa penurunan emisi gas buang yang paling baik adalah pada variasi massa karbon aktif 200 gram dengan persentase penurunan kadar emisi sebesar $8,14 \%$.

Berdasarkan ketiga grafik di atas dapat disimpulkan bahwa penambahan adsorben dapat menurunkan emisi gas buang sepeda motor. Pada putaran $2500 \mathrm{rpm}$ emisi gas buang sedikit rendah karena campuran bahan bakar dan oksigen kurus. Setelah putaran mesin naik menuju 3000-3500 rpm emisi gas buang turun karena campuran bahan bakar dan oksigen mendekati stoikiometri. Ketika putaran mesin tinggi (4500-6500 rpm) campuran bahan bakar dan oksigen semakin kaya sehingga dapat menimbulkan emisi gas buang meningkat karena kekurangan oksigen.

\begin{tabular}{|c|c|c|c|c|c|c|}
\hline $\begin{array}{l}\text { Source of } \\
\text { Variation }\end{array}$ & SS & $d f$ & MS & $F$ & P-value & F crit \\
\hline Rows & 0,083805 & 2 & 0,041902 & 6,360051 & 0,009278 & 3,633723 \\
\hline Columns & 0,795542 & 8 & 0,099443 & 15,09367 & $4,17 \mathrm{E}-06$ & 2,591096 \\
\hline Error & 0,105414 & 16 & 0,006588 & & & \\
\hline Total & 0,98476 & 26 & & & & \\
\hline
\end{tabular}

Gambar 9 Tabel anova pengaruh penambahan adsorben (column) dan putaran mesin (rows) terhadap emisi CO

Hasil analisis menggunakan two way anova menunjukkan bahwa $p$-value $=4,17 \mathrm{E}-06$ dan 0,009278 lebih kecil dari taraf signifikansi atau $\alpha$ $(0,05)$ serta $F$ hitung $=15,09367$ dan 6,360051lebih besar daripada $F$ tabel $=2,591096$ dan 3,633723 maka $\mathrm{H}_{0}$ ditolak dan $\mathrm{H}_{1}$ diterima. Dengan demikian berarti terdapat pengaruh yang signifikan antara penambahan adsorben dan putaran mesin terhadap emisi $\mathrm{CO}$.

\begin{tabular}{|c|c|c|c|c|c|c|}
\hline $\begin{array}{l}\text { Source of } \\
\text { Variation }\end{array}$ & SS & $d f$ & MS & $F$ & P-value & F crit \\
\hline Rows & 0,294785 & 2 & 0,147393 & 11,37354 & 0,000845 & 3,633723 \\
\hline Columns & 6,337274 & 8 & 0,792159 & 61,12689 & $1,54 \mathrm{E}-10$ & 2,591096 \\
\hline Error & 0,207348 & 16 & 0,012959 & & & \\
\hline Total & 6,839407 & 26 & & & & \\
\hline
\end{tabular}

Gambar 10 Tabel anova pengaruh penambahan adsorben (column) dan putaran mesin (rows) terhadap emisi $\mathrm{HC}$

Hasil analisis menggunakan two way anova menunjukkan bahwa $p$-value $=3,05 \mathrm{E}-05$ dan 3,81E05 lebih kecil dari taraf signifikansi atau $\alpha(0,05)$ serta $F$ hitung $=15,8028$ dan 20,53851 lebih besar daripada $F$ tabel $=2,591096$ dan 3,633723 maka $\mathrm{H}_{0}$ ditolak dan $\mathrm{H}_{1}$ diterima. Dengan demikian berarti terdapat pengaruh yang signifikan antara penambahan adsorben dan putaran mesin terhadap emisi HC.

\begin{tabular}{|c|c|c|c|c|c|c|}
\hline $\begin{array}{l}\text { Source of } \\
\text { Variation }\end{array}$ & SS & $d f$ & MS & $F$ & $P$-value & F crit \\
\hline & & & & & $3,81 \mathrm{E}-$ & \\
\hline \multirow[t]{2}{*}{ Rows } & 591,8096 & 2 & 295,9048 & 20,53851 & 05 & 3,633723 \\
\hline & & & & & $3,05 \mathrm{E}-$ & \\
\hline Columns & 1821,407 & 8 & 227,6759 & 15,8028 & 06 & 2,591096 \\
\hline Error & 230,517 & 16 & 14,40731 & & & \\
\hline Total & 2643,734 & 26 & & & & \\
\hline
\end{tabular}

Gambar 11 Tabel anova pengaruh penambahan adsorben (column) dan putaran mesin (rows) terhadap emisi $\mathrm{CO}_{2}$

Hasil analisis menggunakan two way anova menunjukkan bahwa $p$-value $=1,54 \mathrm{E}-10$ dan 0,000845 lebih kecil dari taraf signifikansi atau $\alpha$ $(0,05)$ serta $F$ hitung $=61,12689$ dan 11,37354 lebih 
besar daripada $F$ tabel $=2,591096$ dan 3,633723 maka $\mathrm{H}_{0}$ ditolak dan $\mathrm{H}_{1}$ diterima. Dengan demikian berarti terdapat pengaruh yang signifikan antara penambahan adsorben dan putaran mesin terhadap emisi $\mathrm{CO}_{2}$

Berdasarkan hasil analisis di atas dapat disimpulkan bahwa terdapat pengaruh yang signifikan antara penambahan adsorben dan putaran mesin dengan emisi gas buang.

\section{PENUTUP}

\section{Simpulan}

Dari hasil penelitian yang sudah dilakukan, dapat diambil kesimpulan sebagai berikut:

1. Penambahan adsorben memberikan perbedaan yang signifikan terhadap emisi gas buang $\mathrm{CO}, \mathrm{HC}$, dan $\mathrm{CO}_{2}$.

2. Penurunan emisi gas buang terbaik menggunakan karbon aktif 200 gram.

3. Terjadi penurunan emisi gas buang dengan persentase CO sebesar 12,06\%, HC 17,58\%, dan $\mathrm{CO}_{2} 8,14 \%$ pada penggunaan adsorben karbon aktif 200 gram.

\section{Saran}

Dari hasil penelitian yang telah dilakukan dapat diambil saran sebagai berikut:

1. Gunakan aktivator larutan $\mathrm{NaCl}$ dengan konsentrasi yang lebih tinggi supaya dihasilkan kualitas karbon aktif yang lebih baik..

2. Penelitian lebih lanjut dapat melakukan uji efektivitas karbon aktif dari kulit tempurung kelapa dibanding karbon aktif dari bahan lainnya.

\section{DAFTAR PUSTAKA}

Basuki, Kris Tri. 2007. Penurunan Konsentrasi CO Dan $\mathrm{NO}_{2}$ Pada Emisi Gas Buang Dengan Menggunakan Media Penyisipan $\mathrm{TiO}_{2}$ Lokal Pada Karbon Aktif. JFN Vol. 1. No. 1. 2007.

Dirga, A. 2012. Analisis Kadar Emisi Gas Karbon Monoksida (CO) Dari Kendaraan Bermotor Yang Melalui Penyerap Karbon Aktif Dari Kulit Buah Durian (Durio zibethinus). Skripsi Universitas Hasanuddin, Makassar.

Ismiyati, I., Marlita, D., \& Saidah, D. 2014. Pencemaran udara akibat emisi gas buang kendaraan bermotor. Jurnal Manajemen Transportasi \& Logistik, 1(3), 241-248.

Erawati E., \& Fernando, A. 2018. Pengaruh Jenis Aktifator Dan Ukuran Karbon Aktif Terhadap Pembuatan Adsorbent Dari Serbuk Gergaji Kayu Sengon (ParaserianthesFalcataria. Jurnal Integrasi Proses Vol. 7. No. 2. 2018.
Ramdja, A. F., Halim, M., \& Handi, J. (2008). Pembuatan karbon aktif dari pelepah kelapa (Cocus nucifera). Jurnal Teknik Kimia, 15(2).

Redha, F., Junaidy, R., \& Hasmita, I. 2018. Penyerapan Emisi Co Dan Nox Pada Gas Buang Kendaraan Menggunakan Karbon Aktif Dari Kulit Cangkang Biji Kopi. Biopropal Industri, 9(1), 37-47.

Setiawati, E., \& Suroto. 2010. Pengaruh Bahan Aktivator Pada Pembuatan Karbon Aktif Tempurung Kelapa. Jurnal Riset Industri Hasil Hutan Vol. 2. No. 1. 2010.

Sujatno, A., Salam, R., Bandriyana, \& Dimyati, A. 2015. Studi Scanning Electron Microscopy (SEM) Untuk Karakterisasi Proses Oxidasi Paduan Zirkonium. Jurnal Forum Nuklir (JFN) Vol. 9. No. 2. 2015.

Tirono, M., Sabit, A. 2011. Efek Suhu Pada Proses Pengarangan Terhadap Nilai Kalor Arang Tempurung Kelapa (Coconut Shell Charcoal). Jurnal Neutrino V01. 3. N0. 2. 2011.

Wicaksana, Anton. 2016. Pengaruh Penggunaan Karbon Aktif Pada Saluran Buang Terhadap Emisi Gas Buang Sepeda Motor. Skripsi. Jurusan Teknik Mesin Fakultas Teknik. Universitas Negeri Semarang. 